\title{
PERBEKALAN MELAUT PADA UNIT PENANGKAPAN BOUKE AMI DI PELABUHAN PERIKANAN NUSANTARA MUARA ANGKE JAKARTA
}

\section{SUPPLIES AT BOUKE AMI FISHERIES AT THE MUARA ANGKE FISHING PORT IN JAKARTA}

\author{
Fidratul Ikhsan, Julia Eka Astarini, Fis Purwangka \\ Departemen Pemanfaatan Sumberdaya Perikanan, \\ Fakultas Perikanan dan Ilmu Kelautan, IPB University \\ Korespondensi: fis@psp-ipb.org
}

\begin{abstract}
Provision of fishing supplies is ones of the important economic activity that determining fishing and processing on fishing catches business, especially on ships that sail for a relatively long time. This research was conducted in FebruaryMarch 2020 at the Muara Angke Archipelago Fishery Port, Jakarta Province which aims to identify the type of supply needs at the Bouke ami Fishing Unit, calculate the actual number of supplies at the Bouke ami Fishing Unit, and determine the supply handling system at the Bouke ami Fishing Unit. Data collection method uses a survey method with interview and questionnaire techniques. The sampling technique was purposive sampling. The data obtained were analyzed descriptively qualitative and quantitative. The types of supplies needed at the Bouke ami Fishing Unit are diesel, lubricant, oil, clean water, rice, granulated sugar, carrots, cabbage, pumpkin, tea, coffee, instant noodles, medicine, gas, and cigarettes. The actual number of supplies needed for the Bouke ami Fishing unit depends on the number of crew members, the GT size of the ship, the fishing area, and the fishing time length. The handling system of each supply of rice, vegetables, instant noodles is stored in a refrigerated hatch so it does not rot easily, while oil, diesel are placed behind the ship, and medicines, sugar, coffee, cigarettes are placed in the ship captain's room.
\end{abstract}

Keywords: bouke ami, hatch, ship captain

\begin{abstract}
ABSTRAK
Penyediaan perbekalan melaut merupakan salah satu aktivitas ekonomi yang penting dalam menentukan usaha penangkapan ikan dan pengolahan hasil tangkapan terutama pada kapal yang melaut dalam waktu yang relatif lama. Kapal yang melaut pada waktu yang lama sering mengalami kekurangan perbekalan, sehingga mempengaruhi kegiatan penangkapan bahkan hasil tangkapan. Penelitian ini dilaksanakan pada bulan Februari-Maret 2020 yang bertempat di Pelabuhan Perikanan Nusantara Muara Angke, Kota Jakarta, Provinsi DKI Jakarta yang bertujuan untuk mengidentifikasi jenis kebutuhan perbekalan pada unit penangkapan bouke ami, menghitung jumlah aktual kebutuhan perbekalan pada unit penangkapan bouke ami dan menentukan sistem penanganan perbekalan pada unit penangkapan bouke ami. Metode pengumpulan data yang digunakan adalah metode survei dengan teknik wawancara dan kuesioner. Teknik pengambilan sampel menggunakan metode purposive sampling. Data yang didapatkan dianalisis secara deskriptif kualitatif dan kuantitatif. Hasil penelitian menunjukkan bahwa jenis kebutuhan perbekalan pada unit penangkapan bonke ami yaitu, solar, oli, minyak, air bersih, beras, gula pasir, wortel, kol, labu, teh, kopi, mie instant, obat-obatan, gas, dan rokok. Jumlah aktual kebutuhan perbekalan unit penangkapan bouke ami disebabkan oleh faktor jumlah ABK, ukuran GT kapal, daerah penangkapan ikan, dan lama melaut. Sistem penanganan masing-masing perbekalan beras, sayuran, mie instan disimpan di palka berpendingin agar tidak mudah busuk, sedangkan oli, solar diletakkan di belakang kapal, dan obat-obatan, gula, kopi, dan rokok diletakkan di kamar nakhoda.
\end{abstract}

Kata kunci: bouke ami, nakhoda, palka 


\section{PENDAHULUAN}

Sektor kelautan dan perikanan Indonesia masih menghadapi berbagai tantangan, antara lain daya saing produk yang masih rendah, tidak berkembangnya pasar domestik, terbatasnya akses permodalan untuk pengembangan usaha, teknologi dan kualitas nelayan yang masih rendah, kegiatan illegal, unregulated, and unreported (IUU) fishing, overfishing, serta lemahnya kelembagaan pengawasan dan sistem pendataan perikanan tangkap. Menurut nelayan, saat ini lokasi penangkapan yang semula ditemui banyak ikan, tidak lagi menunjukkan hal yang sama. Hal ini mengharuskan nelayan untuk mencari lokasi penangkapan lain yang jaraknya lebih jauh serta membutuhkan waktu melaut yang lebih lama.

Lamanya waktu melaut berpengaruh terhadap bertambahnya kebutuhan perbekalan. Terkait hal ini, kekurangan perbekalan selama kegiatan penangkapan sering terjadi. Perbekalan yang tidak mencukupi selama perjalanan melaut dapat berisiko membahayakan keselamatan nelayan. Contoh kasus yang pernah dilaporkan adalah terjadinya kecelakaan kapal yang tengah melaut akibat kekurangan bahan bakar dan mengakibatkan kapal tenggelam (Nugroho 2019). Selain itu, permasalahan yang juga ditemui adalah data perbekalan yang diisi sebelum perjalanan melaut sering ditemukan pengisiannya yang belum sesuai dan masih asal-asalan. Padahal pengisian data tersebut sangat penting dilakukan untuk mengantisipasi kekurangan perbekalan selama kegiatan penangkapan.

Kebutuhan perbekalan kapal penangkap ikan sangat penting dalam berjalannya kegiatan penangkapan ikan yang ditujukan untuk membekali nelayan atau awak kapal selama perjalanan melaut. Perbekalan tersebut meliputi solar, oli, es, air bersih, garam, dan bahan makanan (Fitriyashari et al. 2014). Perbekalan mencakup semua barang yang diperlukan baik barang bergerak maupun barang tidak bergerak sebagai sarana pendukung pelaksanaan tugas (Dinita et al. 2015). Kebutuhan perbekalan dapat dicukupi dengan melakukan manajemen perbekalan meliputi perencanaan, pengorganisasian, dan pengawasan terhadap kegiatan pengadaan, pencatatan, pendistribusian, penyimpanan, pemeliharaan perbekalan guna mendukung efektivitas dan efisiensi dalam upaya pencapaian tujuan organisasi terutama pada kapal dengan trip penangkapan yang relatif lama (Saleh 2016). Salah satu kegiatan kapal perikanan di pelabuhan yang bertujuan untuk mempersiapkan perbekalan untuk kegiatan operasi penangkapan ikan adalah kegiatan bongkar muat.

Berdasarkan undang-undang no 9 tahun 1985 tentang perikanan, salah satu fungsi Pelabuhan Perikanan (PP) maupun Pangkalan Pendaratan Ikan (PPI) adalah melayani kegiatan kapalkapal perikanan. Pelabuhan Perikanan Nusantara (PPN) Muara Angke merupakan salah satu pusat perikanan nasional yang memiliki hasil produksi yang tinggi. Hasil tangkapan tersebut sudah memiliki tujuan distribusinya. Tujuan distribusi utama hasil tangkapan PPN Muara Angke adalah Kota Jakarta Utara, daerah sekitar Jakarta dan ekspor. Jumlah armada kapal perikanan terdaftar di PPN Muara Angke hingga Februari 2020 berjumlah 1.539 kapal dan didominasi oleh kapal bouke ami sebanyak 822 kapal (UPT Muara Angke 2020). Jaring cumi atau bouke ami adalah alat tangkap yang dikelompokkan ke dalam jenis alat tangkap jaring angkat, terdiri dari bahan jaring berbentuk segi empat dilengkapi bingkai bambu atau bahan lainnya sebagai rangka, yang dioperasikan dengan cara dibenamkan pada kolom perairan saat setting dan diangkat ke permukaan saat hauling (KEPMEN No 6 2010). PPN Muara Angke mempunyai sarana penunjang yang memadai dan letaknya strategis sebagai pusat pemasaran ikan di Jakarta. Namun, informasi mengenai data perbekalan di pelabuhan ini masih belum lengkap dan akurat.

Oleh karena itu, pada penelitian ini akan ditelaah mengenai perbekalan melaut berdasarkan jenis-jenisnya, jumlah aktual, dan cara penanganannya. Selain itu memberikan rekomendasi perbekalan melaut kepada nelayan kapal bouke ami di PPN Muara Angke agar dapat menjamin keselamatan saat pelaksanaan operasi penangkapan ikan serta efisiensi dan efektivitas biaya perbekalan yang dikeluarkan. Berdasarkan latar belakang yang telah dipaparkan, maka tujuan dari penelitian ini adalah mendeskripsikan penangkapan bouke ami di Pelabuhan Perikanan Nusantara Muara Angke Jakarta, mengidentifikasi jenis kebutuhan perbekalan, dan menghitung jumlah aktual kebutuhan perbekalan, serta menentukan sistem penanganannya. 


\section{METODE PENELITIAN}

Penelitian telah dilaksanakan pada bulan Februari-Maret 2020 yang bertempat di Pelabuhan Perikanan Nusantara Muara Angke, Kota Jakarta, Provinsi DKI Jakarta. Penelitian ini terdapat beberapa jenis data. Data yang dikumpulkan dalam setiap tujuan dapat dilihat pada Tabel 1 .

Metode pengumpulan data dilakukan dengan observasi dan wawancara mendalam.
Melalui wawancara inilah peneliti menggali data informasi dan kerangka keterangan dari subyek penelitian. Teknik wawancara yang dilakukan adalah pertanyaan yang dilontarkan tidak terpaku pada pedoman wawancara dan dapat diperdalam maupun dikembangkan sesuai dengan situasi dan kondisi lapangan. Wawancara dilakukan kepada nahkoda unit penangkapan bouke ami di Pelabuhan Perikanan Nusantara Muara Angke Jakarta.

Tabel 1. Jenis dan teknik pengumpulan data

\begin{tabular}{|c|c|c|c|c|}
\hline Tujuan & Jenis Data & $\begin{array}{c}\text { Teknik } \\
\text { Pengumpulan } \\
\text { Data }\end{array}$ & Sumber Data & $\begin{array}{c}\text { Analisis } \\
\text { Data }\end{array}$ \\
\hline $\begin{array}{l}\text { Mendeskripsikan } \\
\text { penangkapan bouke } \\
\text { ami di Pelabuhan } \\
\text { Perikanan Nusantara } \\
\text { Muara Angke } \\
\text { Jakarta }\end{array}$ & $\begin{array}{l}\text { Alat tangkap, } \\
\text { kapal, metode } \\
\text { penangkapan, } \\
\text { nelayan, } \\
\text { hasil tangkapan, } \\
\text { daerah } \\
\text { penangkapan }\end{array}$ & $\begin{array}{l}\text { Observasi, } \\
\text { wawancara, } \\
\text { dan studi } \\
\text { pustaka }\end{array}$ & $\begin{array}{l}\text { ABK, nakhoda } \\
\text { unit penangkapan, } \\
\text { referensi terkait } \\
\text { unit penangkapan } \\
\text { bouke ami }\end{array}$ & $\begin{array}{l}\text { Deskriptif } \\
\text { kualitatif } \\
\text { dan } \\
\text { kuantiatif }\end{array}$ \\
\hline $\begin{array}{l}\text { Mengidentifikasi } \\
\text { jenis kebutuhan } \\
\text { perbekalan pada unit } \\
\text { penangkapan bouke } \\
\text { ami di Pelabuhan } \\
\text { Perikanan Nusantara } \\
\text { Muara Angke } \\
\text { Jakarta }\end{array}$ & $\begin{array}{l}\text { Perbekalan } \\
\text { melaut solar, oli, } \\
\text { air bersih, bahan } \\
\text { makanan, } \\
\text { jumlah masing- } \\
\text { masing } \\
\text { perbekalan }\end{array}$ & $\begin{array}{l}\text { Observasi dan } \\
\text { wawancara } \\
\text { mendalam }\end{array}$ & $\begin{array}{l}\text { ABK unit } \\
\text { penangkapan } \\
\text { bagian perbeka- } \\
\text { lan/perwira unit } \\
\text { penangkapan/ } \\
\text { pemilik kapal dan } \\
\text { supplier } \\
\text { perbekalan }\end{array}$ & $\begin{array}{l}\text { Deskriptif } \\
\text { kualitatif } \\
\text { dan } \\
\text { kuantiatif }\end{array}$ \\
\hline $\begin{array}{l}\text { Menghitung jumlah } \\
\text { aktual kebutuhan } \\
\text { perbekalan pada unit } \\
\text { penangkapan bouke } \\
\text { ami di Pelabuhan } \\
\text { Perikanan Nusantara } \\
\text { Muara Angke } \\
\text { Jakarta }\end{array}$ & $\begin{array}{l}\text { Jenis } \\
\text { perbekalan, } \\
\text { ukuran kapal } \\
\text { jumlah masing- } \\
\text { masing perbeka- } \\
\text { lan }\end{array}$ & $\begin{array}{l}\text { Observasi dan } \\
\text { wawancara } \\
\text { mendalam }\end{array}$ & $\begin{array}{l}\text { ABK unit } \\
\text { penangkapan } \\
\text { bagian perbeka- } \\
\text { lan/perwira unit } \\
\text { penangkapan/ } \\
\text { Pemilik kapal, } \\
\text { supplier } \\
\text { perbekalan dan } \\
\text { UPT PPN Muara } \\
\text { Angke }\end{array}$ & $\begin{array}{l}\text { Deskriptif } \\
\text { kualitatif } \\
\text { dan } \\
\text { deskriptif } \\
\text { kuantiatif }\end{array}$ \\
\hline $\begin{array}{l}\text { Menentukan sistem } \\
\text { penanganan } \\
\text { perbekalan pada unit } \\
\text { penangkapan bouke } \\
\text { ami di Pelabuhan } \\
\text { Perikanan Nusantara } \\
\text { Muara Angke } \\
\text { Jakarta }\end{array}$ & $\begin{array}{l}\text { Jenis } \\
\text { perbekalan, tata } \\
\text { letak perbekalan } \\
\text { kapal, aturan } \\
\text { dan SOP } \\
\text { perbekalan } \\
\text { kapal bouke ami }\end{array}$ & $\begin{array}{l}\text { Observasi dan } \\
\text { wawancara } \\
\text { mendalam }\end{array}$ & $\begin{array}{l}\text { ABK unit } \\
\text { penangkapan } \\
\text { bagian perbeka- } \\
\text { lan/perwira unit } \\
\text { penangkapan/ } \\
\text { Pemilik kapal, } \\
\text { supplier perbeka- } \\
\text { lan dan UPT PPN } \\
\text { Muara Angke }\end{array}$ & $\begin{array}{l}\text { Deskriptif } \\
\text { kualitatif } \\
\text { dan } \\
\text { deskriptif } \\
\text { kuantiatif }\end{array}$ \\
\hline
\end{tabular}


Teknik dalam pengambilan sampel dalam penelitian ini adalah purposive sampling. Purposive sampling menurut Sugiyono adalah teknik penentuan sampel dengan pertimbangan tertentu (Sugiyono 2010). Adapun syarat untuk mengambil sampel adalah:

1. Berdasarkan kapal yang menggunakan perbekalan dan yang berlabuh di PPN Muara Angke Jakarta, yaitu bouke ami.

2. Nelayan yang mengetahui semua kegiatan yang berhubungan dengan perbekalan kapal tersebut yaitu pemilik kapal atau nahkoda kapal

3. Nelayan atau nahkoda kapal yang mengetahui kebutuhan solar, air bersih, oli, dan bahan makanan pada kapal bouke ami.

4. Nelayan atau nahkoda kapal yang memiliki pengalaman kerja berlayar minimal selama 10 tahun.

Jumlah kapal bouke ami yang berpangkalan di PPN Muara Angke Jakarta saat penelitian dilakukan adalah $253 \mathrm{kapal}$, sehingga peneliti mengambil 10\% dari jumlah kapal menjadi responden yang peneliti ambil yaitu sebanyak 25 kapal. Peneliti menemukan kapal yang berukuran <30 GT sebanyak 8 kapal, kapal yang berukuran 31-50 GT sebanyak 5 kapal, dan kapal yang berukuran 51-100 GT sebanyak 12 kapal. Menurut (Sugiyono 2010), banyaknya sampel yang diambil dapat dihitung dengan menghitung $10 \%$ dari populasi kapal yang berlabuh di PPN Muara Angke setiap hari.

Penanganan perbekalan melaut dimulai dengan mendeskripsikan unit penangkapan bouke ami menggunakan metode analisis deskriptif dengan memberi gambaran terkait dianalisis dengan mendeskripsikan unit penangkapan bouke ami yang mencakup alat tangkap, kapal, nelayan, daerah penangkapan, musim penangkapan, dan juga mencakup data perbekalan. Tahap selanjutnya adalah dengan mengidentifikasi jenis kebutuhan perbekalan dengan pendekatan mengidentifikasi jenis kegiatan yang terdapat dalam unit penangkapan bouke ami tentang apa, mengapa, dan siapa yang menggunakannya agar dapat diketahui jenis perbekalan atau perlengkapan yang dibutuhkan, terutama mengenai tipe, ukuran, mutu, termasuk harganya. Tahap ke tiga adalah menghitung jumlah aktual kebutuhan perbekalan dengan mengidentifikasi volume dan frekuensi kegiatan yang terdapat dalam unit penangkapan bouke amiagar dapat diperoleh gambaran jumlah perlengkapan yang diperlukan dan bagaimana penggunaannya. Tahap terakhir adalah menentukan sistem penanganan perbekalannya dengan melakukan analisis statistik deskriptif yang dilakukan berupa pembuatan tabel-tabel ataupun grafik-grafik untuk menyajikan hasil dari observasi dan wawancara mendalam dalam bentuk kuesioner terhadap nahkoda unit penangkapan bouke ami.

\section{HASIL DAN PEMBAHASAN}

\section{Unit penangkapan bouke ami}

Menurut Rifan et al. (2016) Pangkalan Pendaratan Ikan Muara Angke sebagian besar 20-30 GT dan ada jumlah kapal yang di atas 30 GT yang mendukung kegiatan penangkapan ikan di perairan wilayah lepas pantai dan regional. Alat tangkap jaring cumi (bouke ami) mulai banyak digunakan oleh nelayan-nelayan PPN Muara Angke akibat banyak yang berpindah alat tangkap yang lainnya, seperti purse seine, bubu, gillnet menjadi menggunakan alat tangkap bouke ami karena bouke ami dinilai lebih menguntungkan disamping hasil tangkapan cumi-cumi memiliki harga jual tinggi, selain itu pada penggunaannya terdapat 2 alat tangkap yaitu jaring cumi dan pancing cumi.

Bouke ami adalah jenis alat tangkap pada umumnya menangkap hasil tangkapan yang bersifat phototaxis positif (Monintja dan Martasuganda 1989). Mata jaring pada bouke ami umumnya berbeda-beda pada setiap bagian jaringnya. Bagian jaring terdiri dari kantong jaring, badan jaring, dan kaki jaring yang terbuat dari bahan Polyamide (PA). Polyamide yang memiliki karakteristik jaring lentur, kuat, mudah tenggelam, dan elastisitas tinggi. Menurut Yahya dan Ilhamdi (2018) bouke ami jaring berbentuk mengerucut dengan panjang antara 14$20 \mathrm{~m}$ dan diameter mulut jaring berkisar antara 12-20 m, menggunakan ukuran jaring dan ukuran mata jaring yang berbeda pada setiap bagian jaringnya. Bagian pada kaki jaring atau srampatan dengan ukuran benang d/48 dan ukuran mata jaring adalah 3 inch, srampatan berguna untuk melindungi bagian tepi jaring utama yang diikat pada tali ris atas dan tali ris bawah agar bagian pinggir jaring tidak sobek ataupun rusak seperti terlihat pada Gambar 1 dan 2.

Menurut Sudirman dan Mallawa 
(2012) jaring bouke ami menggunakan pemberat dengan jenis timah berat satuan 250 gram per buah dan dipasang di bagian srampatan kaki jaring sehingga untuk sekeliling kaki jaring membutuhkan 1.0001.500 pemberat dengan berat total berkisar $250-400 \mathrm{~kg}$, dan menggunakan cincin sebanyak 60-80 cincin yang berukuran $3^{1 / 2}$ inch dengan berat satuan 400 gram. Fungsi pemberat untuk menenggelamkan jaring sampai pada dasar perairan untuk menjerat cumi dan ikan yang berada di bawah permukaan air, sedangkan cincin berfungsi untuk tempat melingkarkan tali kerut saat menutup mulut jaring, cincin selain itu berfungsi juga sebagai pemberat, sehingga cumi terperangkap masuk ke dalam badan jaring sampai ke kantong jaring. Secara umum, spesifikasi alat tangkap bouke ami

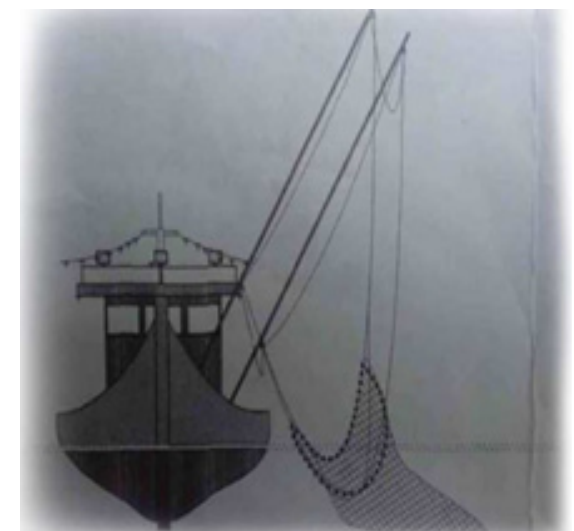

Sumber: Rooskandar (2014)

Gambar 1. Kapal bouke ami saat pengoperasian jaring dapat dilihat pada Tabel 2 .

Alat bantu penangkapan bouke ami sangat penting dalam kegiatan penangkapan, umumnya alat yang digunakan unit penangkapan bouke ami adalah lampu, gardan, dan bingkai/lewang. Lampu berfungsi untuk mengumpulkan cumi dan ikan. Alat bantu selanjutnya yaitu gardan digunakan untuk menurunkan dan menaikkan jaring ke kapal, dan selanjutnya bingkai atau lewang digunakan untuk membuka mulut jaring pada saat diturunkan pada daerah penangkapan dan membantu dalam menaikkan hasil tangkapan, selain itu lewang juga menggunakan tali penarik yang berfungsi untuk membentangkan jaring pada saat pengoperasian dan menahan sementara jaring sebelum jaring.

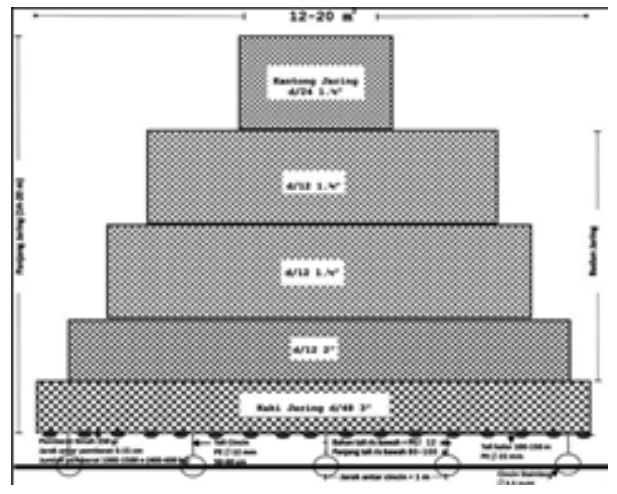

Sumber: Yahya dan Ilhamdi (2018)

Gambar 2. Desain jaring bouke ami

Tabel 2. Spesifikasi alat tangkap bouke ami

\begin{tabular}{lll}
\hline \multicolumn{1}{c}{ Bagian alat } & \multicolumn{1}{c}{ Bahan } & \multicolumn{1}{c}{ Keterangan } \\
\hline Bagian jaring & & \\
1. Kantong & Polyamide (PA) & Mesh size 1 inch \\
2. Badan jaring & Polyamide (PA) & Mesh size 1-2 inch \\
3. Kaki jaring & Polyamide (PA) & Mesh size 3 inch \\
Bagian tali & & \\
1. Tali kolor & Polyethylene (PE) & Diameter 2,2 cm, panjang 40-50 m \\
2. Tali kerek & Polyethylene (PE) & Diameter 3,2 cm, panjang 20-60 m \\
Bagian lainnya & & \\
1. Pemberat & Timah & 300 gr, 150-600 buah \\
2. Cincin & Stainless/Kuningan & 500 gr, 40-90 buah \\
3. Rig & Besi & Panjang 10-20 m, 2 buah \\
\hline
\end{tabular}

Sumber: Kotdriyah (2019) 
Kapal bouke ami yang berada di PPN Muara Angke umumnya terbuat dari bahan kayu. Kapal tersebut digerakkan menggunakan inboard engine dengan bahan bakar solar campuran bensin dan minyak tanah. Hampir semua kapal bouke ami dilengkapi dengan fasilitas freezer. Freezer tersebut diletakkan di palka digunakan untuk menyimpan hasil tangkapan agar mutunya tetap terjaga. Dengan adanya fasilitas freezer, nelayan bouke ami dapat beroperasi dalam waktu lebih lama dan fishing ground lebih jauh.

Menurut Kotdriyah (2019) panjang kapal yang digunakan Angke 9,35 - 29,60 $\mathrm{m}$, lebar 3,60 - 9,12 m, dan dalam 1,30 3,20 m. Kapal bouke ami di PPN Muara Angke terbuat dari bahan kayu dengan mesin penggerak merk Mitsubishi, Nissan, Yanmar, Hino, Hyundai, Dongfeng dan memiliki kekuatan berkisar 56-500 PK. Kapal bouke ami umumnya memiliki dua hingga tiga mesin yang digunakan sebagai mesin penggerak dan mesin bantu untuk lampu dan palka. Kapal bouke ami di PPN Muara Angke sudah dilengkapi dengan palka berpendingin. Jumlah palka berkisar berkisar antara 3-12 unit dengan kapasitas palka 2-6 ton. Selain palka, kapal bouke ami juga dilengkapi winch hauler, radio contact, VMS (Vessel Monitoring System). Winch hauler digunakan untuk menaikkan alat tangkap ke atas kapal, radio contact untuk berkomunikasi dengan kapal lain atau pihak pelabuhan, dan VMS untuk mempermudah pengawasan dan pemantauan terhadap posisi kapal.

Metode penangkapan bouke ami dibagi menjadi 3 tahap, yaitu persiapan, setting, dan hauling. Metode penangkapan bouke ami dapat dilihat pada Tabel 3.

Menurut Sudirman dan Mallawa (2012) proses penurunan alat tangkap (setting) dilakukan pada jam 8 malam hingga pagi hari jam 5 pagi, tahap awal yang dilakukan yaitu menyiapkan alat tangkap dengan cara mengikat ujung jaring atau bagian kantong jaring, selanjutnya jaring digantung pada 4 sisi lewang dengan bantuan katrol dan gardan, setelah jaring tergantung dengan sempurna nakhoda serta anak buah kapal (ABK) mengamati kondisi cumi dan ikan di bawah perairan. Setelah cumi atau ikan berkumpul maka secara bertahap lampu mulai dimatikan hingga hanya menyisakan satu lampu agar gerombolan cumi terkonsentrasi, selanjutnya jaring bouke ami diturunkan dengan cepat mulai dari cincin.

Nelayan bouke ami di PPN Muara Angke sebagian besar merupakan nelayan penuh, seluruh waktu yang digunakan untuk melakukan kegiatan penangkapan ikan. Nelayan bouke ami terdiri dari pemilik kapal dan nelayan buruh. Nelayan buruh yang berjumlah 9-16 orang. Berikut jabatan dan pembagian tugasnya dapat dilihat pada Tabel 4.

Tabel 3. Metode penangkapan bouke ami

\begin{tabular}{cl}
\hline Tahap & \multicolumn{1}{c}{ Keterangan } \\
\hline Persiapan & $\begin{array}{l}\text { Persiapan perbekalan meliputi, pengisian perbekalan. Menentukan daerah } \\
\text { penangkapan ikan atau disebut fishing ground oleh nahkoda juga sebagai fish- } \\
\text { ing master. Menentukan alur pelayaran menuju fishing ground menggunakan } \\
\\
\text { GPS. Lama perjalanan menuju fishing ground selama 2-3 hari, tergantung pada } \\
\text { jarak fishing ground yang dituju. }\end{array}$ \\
& Tahap setting dilakukan setelah sampai di fishing ground, dimulai dengan mem- \\
& bentangkan rig atau tiang melintang yang terdapat pada sisi kanan kapal dan \\
& mengatur tali-temali pada jaring. Lampu setelah itu semuanya yang terdapat di \\
& sisi kiri dan kanan kapal dinyalakan untuk menarik perhatian cumi-cumi dan \\
& ikan karena cumi-cumi dan sebagian ikan bersifat phototaxis positif. Tunggu \\
& sampai cumi-cumi naik ke permukaan dan mendekat ke kapal. Proses setting \\
& dilakukan pada sore hari sebelum terbenam matahari, berlangsung kira-kira \\
& selama 15-20 menit. \\
& Tahap hauling yaitu menaikkan jaring beserta tangkapannya ke atas kapal. \\
& Saat cumi-cumi telah berkumpul ramai di bawah sekitar kapal, lampu yang \\
Hauling & ada pada kapal perlahan diredupkan hampir semuanya kecuali satu lampu \\
& yang menyala untuk memfokuskan cumi-cumi tertangkap, jaring diangkat dan \\
& hasil tangkapan diambil menggunakan serok. Hauling dilakukan 15 kali dalam \\
& satu malam lebih kurang.
\end{tabular}

Sumber: Hasil wawancara dengan nelayan (2020) 
Tabel 4. Jabatan dan tugas nelayan unit penangkapan bouke ami

\begin{tabular}{|c|c|c|c|}
\hline No & Jabatan & Jumlah & Tugas \\
\hline 1 & Kapten/Nakhoda & 1 & $\begin{array}{l}\text { Pemegang kendali kapal dan menentukan daerah } \\
\text { penangkapan ikan, memerintahkan menjatuhkan } \\
\text { jaring dan mengangkat jaring }\end{array}$ \\
\hline 2 & Wakil kapten & 1 & $\begin{array}{l}\text { Semua yang mencakup kapal, seperti memberi } \\
\text { perintah kepada ABK sesuai arahan kapten }\end{array}$ \\
\hline 3 & Juru mesin & 1 & $\begin{array}{l}\text { Bertanggung jawab atas segala yang berhubungan } \\
\text { dengan mesin kapal dan penggunaan bahan bakar } \\
\text { untuk operasional penangkapan }\end{array}$ \\
\hline 4 & Juru masak & 1 & $\begin{array}{l}\text { Bertanggung jawab atas perbekalan selama opera- } \\
\text { sional serta mempersiapkan makanan kepada ABK, } \\
\text { kapten, dan juru mesin yang bertugas di atas kapal }\end{array}$ \\
\hline 5 & Penata jaring & 2 & $\begin{array}{l}\text { Bertanggung jawab dalam mempersiapkan jaring } \\
\text { sebelum setting dan sesudah hauling. Memperbaiki } \\
\text { kerusakan jaring selama di atas kapal }\end{array}$ \\
\hline 6 & Juru lampu & 2 & $\begin{array}{l}\text { Bertanggung jawab mempersiapkan lampu dan } \\
\text { menyesuaikan besar kecil cahaya lampu }\end{array}$ \\
\hline 7 & $\begin{array}{l}\text { Pengoperasi setting } \\
\text { dan hauling }\end{array}$ & 4 & $\begin{array}{l}\text { Bertanggungjawab dalam menurunkan jaring dan } \\
\text { menaikkan jaring }\end{array}$ \\
\hline
\end{tabular}

Sumber: Alvionita (2018)

\section{Hasil tangkapan}

Hasil tangkapan unit penangkapan bouke ami tidak hanya cumi-cumi namun terdapat berbagai jenis ikan lainnya. Hasil tangkapan dibagi menjadi dua kategori yaitu hasil tangkapan utama dan hasil tangkapan sampingan. Hasil tangkapan nelayan sering dijadikan konsumsi tambahan apabila stok makanan mereka habis selama trip penangkapan. Hasil tangkapan utama unit penangkapan bouke ami adalah cumi-cumi (Loligo sp), beberapa jenis hasil tangkapan sampingan diantaranya, belanak (Mugil chopalus), baronang (Siganus canaliculatus), tenggiri (Scomberomorini), tembang (Sardinella), layang (Decapterus), dan layur (Trichiurus lepturus). Data hasil tangkapan bouke ami dapat dilihat pada Gambar 3.

Dilihat dari Gambar 3 hasil tangkapan dari unit penangkapan bouke ami hasil tangkapan yang paling banyak yaitu cumi-cumi (Loligo $s p$ ) sebanyak 22.924.400, hasil tangkapan cumi paling banyak karena cumi-cumi ini adalah hasil tangkapan utama unit penangkapan bouke ami. Sementara hasil tangkapan sampingan yaitu tenggiri (Scomberomorus commerson) sebanyak 280.381, semampar (Sepia sp) sebanyak 782.261, tembang (Sardinella fimbriata) sebanyak 228.983, selar (Selaroides leptolepis) sebanyak 470.345, tengkek (Megalaspis cordyla) sebanyak 208.963, lemuru (Sardinella lemuru) sebanyak 372.774, layang (Decapterualins lajang) sebanyak 336.407, dan uyer (Leiognathus equulus) sebanyak 183.180.

\section{Daerah penangkapan}

Unit penangkapan bouke ami pada umumnya dioperasikan selama 60-100 hari per trip dengan 3 kali trip per tahunnya. Daerah penangkapan atau fishing ground unit penangkapan bouke ami berdasarkan hasil wawancara, biasanya di WPP 711 meliputi Laut Cina Selatan, Perairan Natuna, dan Selat Karimata dan di WPP 712 meliputi Laut Jawa. Menurut Yahya dan Ilhamdi (2018) daerah penangkapan kapal bouke ami yang berbasis di TPI Muara Angke pada umumnya di perairan dangkal dengan kedalaman berkisar 20-60 m, yaitu di WPP 711 Laut Cina Selatan (Perairan Natuna, Selat Karimata) dan di WPP 712 Laut Jawa (Pangkalan Bun, Tanjung Puting, dan Karimun Jawa).

Daerah Penangkapan Ikan (DPI) dari 25 responden yang diteliti dapat dilihat pada Tabel 5. 
Berdasarkan Tabel 5 dan Gambar 4, hasil wawancara yang dilakukan dari jumlah populasi kapal yang diambil, 14 kapal melakukan penangkapan ikan di daerah WPP 712 yaitu Laut Jawa dan sebanyak 11 kapal melakukan penangkapan ikan di WPP 711 yaitu Laut Natuna dan Selat Karimata, Gambar 4 menyatakan rata-rata kapal melakukan penangkapan ikan di daerah WPP 712 dan WPP 711.

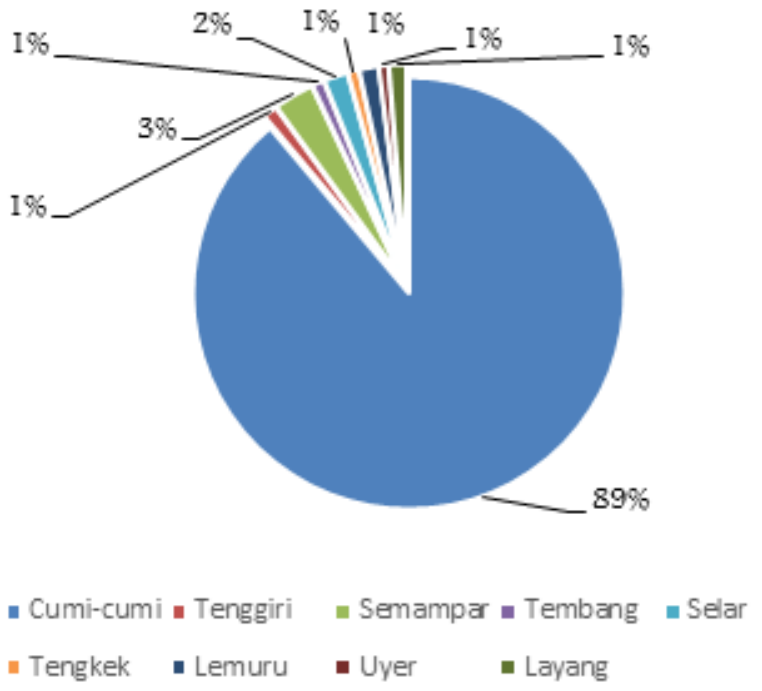

Gambar 3. Komposisi hasil tangkapan unit penangkapan bouke ami

Tabel 5. DPI unit penangkapan bouke ami

\begin{tabular}{clccc}
\hline No & DPI & Jarak & Lama Trip & Jumlah Kapal \\
\hline 1 & WPP 712 & $129,310 \mathrm{mil}$ & $60-100$ Hari & 14 \\
2 & WPP 711 & $400,052 \mathrm{mil}$ & $70-100$ Hari & 11 \\
\hline
\end{tabular}

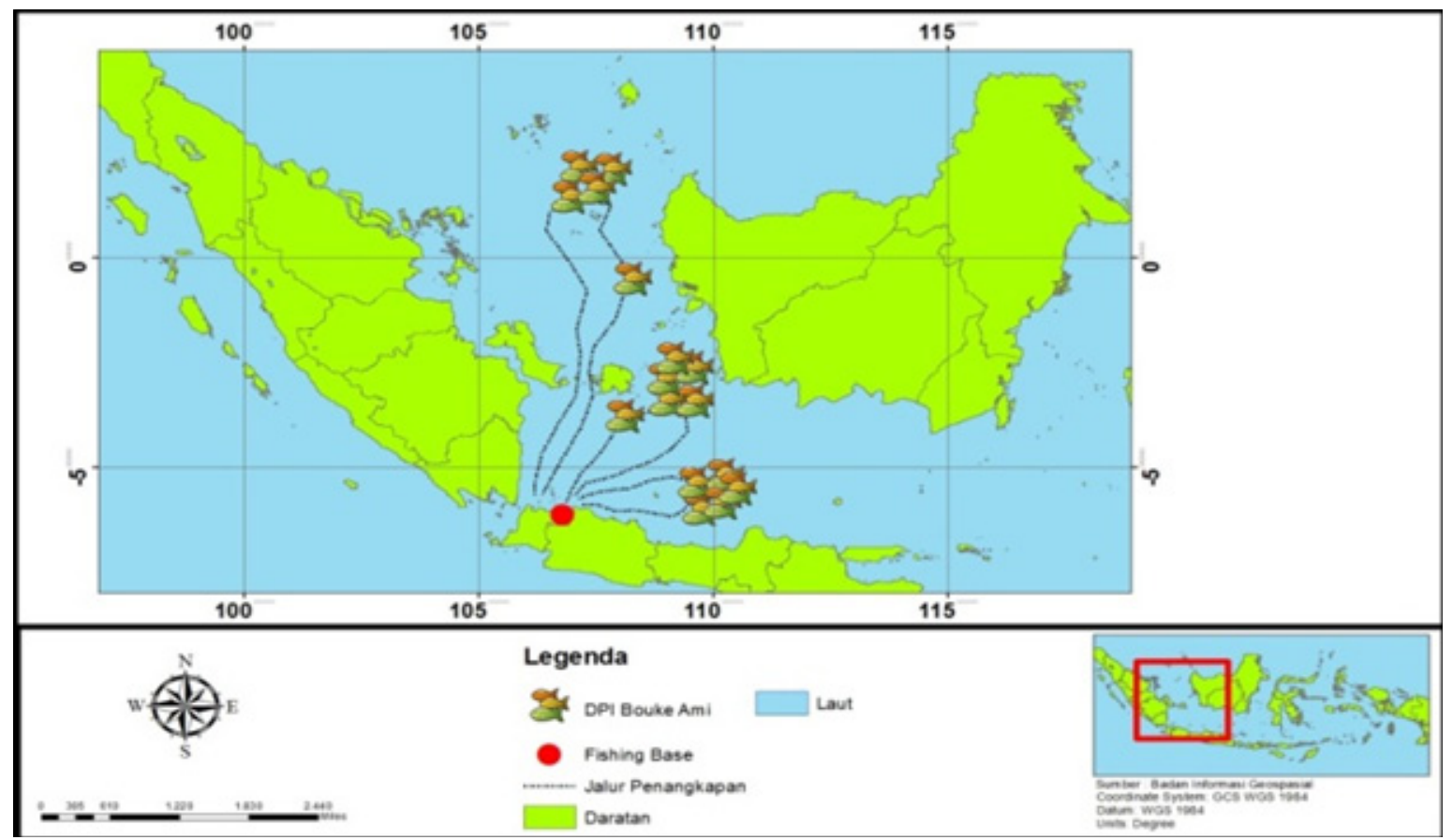

Gambar 4. Peta DPI unit penangkapan bouke ami 
Jenis kebutuhan perbekalan pada unit penangkapan bouke ami di Pelabuhan Perikanan Nusantara Muara Angke Jakarta

Perbekalan unit penangkapan bouke ami sangatlah penting untuk dipersiapkan sebelum melaut. Pemilik kapal biasanya sudah mempunyai agen masing-masing untuk mengurus bagian perbekalan tersebut dan sudah mempunyai toko langganan untuk menyediakan perbekalan. Beberapa perbekalan melaut yang dibutuhkan adalah solar, oli, air bersih, beras, gula pasir, minyak goreng, sayuran berupa wortel, kol dan labu, teh, kopi, mie instan, obat-obatan, gas elpiji, dan rokok.

Unit penangkapan bouke ami berusaha untuk mendapatkan hasil tangkapan sebanyak-banyaknya dengan menambah waktu trip penangkapan ikan. Grafik lama trip penangkapan dapat dilihat pada Gambar 5.

Pada Gambar 5 lama trip masingmasing unit penangkapan bouke ami dilihat dari grafik berbeda-beda dari 60 hari sampai dengan 100 hari paling lama. Lama trip dari kapal yang <30 GT yaitu rata-rata 60,70 , 75 , 90, dan 100 hari sedangkan kapal yang berukuran 31-50 GT lama trip melaut ratarata 60, 90, dan 100 hari dan kapal yang berukuran 51-100 GT lama trip melaut rata-rata 60, 90, dan 100 hari.

ABK berperan penting dalam pengoperasian unit penangkapan bouke ami, untuk memperlancar kegiatan operasi penangkapan. Berikut grafik jumlah ABK unit penangkapan bouke ami (Gambar 6).

Dilihat dari Gambar 6 jumlah ABK unit penangkapan bouke ami berbeda-beda dengan jumlah ABK 9 orang yang paling sedikit pada kapal yang berukuran 29, 30, dan 33 GT sampai dengan 16 orang yang paling banyak. Jumlah ABK pada kapal yang berukuran $<30$ GT berjumlah 16,10 , 9 orang, sedangkan jumlah ABK pada kapal yang berukuran 31-50 GT berjumlah 9, 12, 13 , dan 14 orang dan kapal yang berukuran 51-100 GT berjumlah $12,13,14$, dan 15 orang.

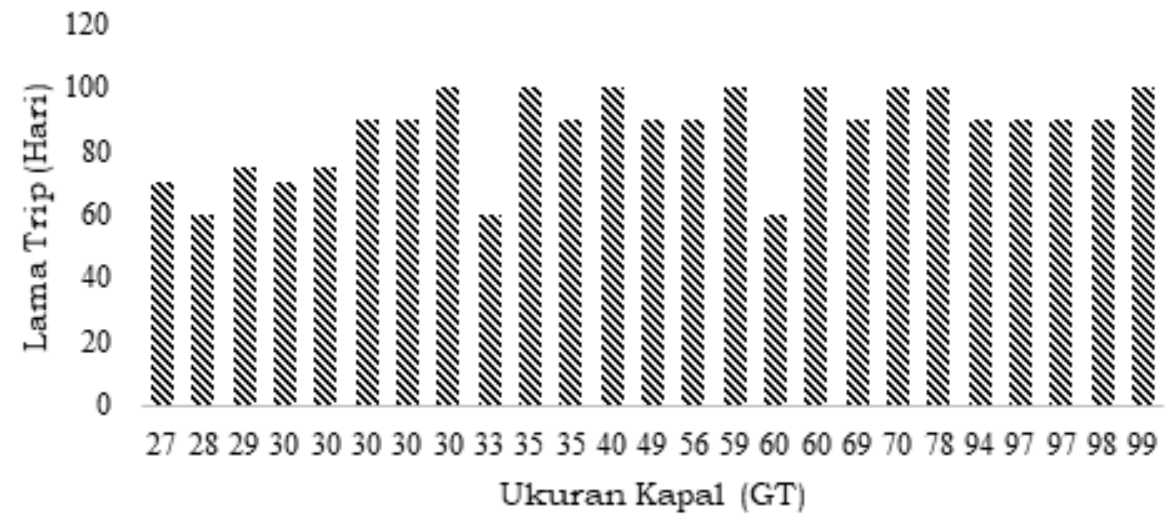

Gambar 5. Grafik lama trip unit penangkapan bouke ami di PPN Muara Angke Tahun 2020

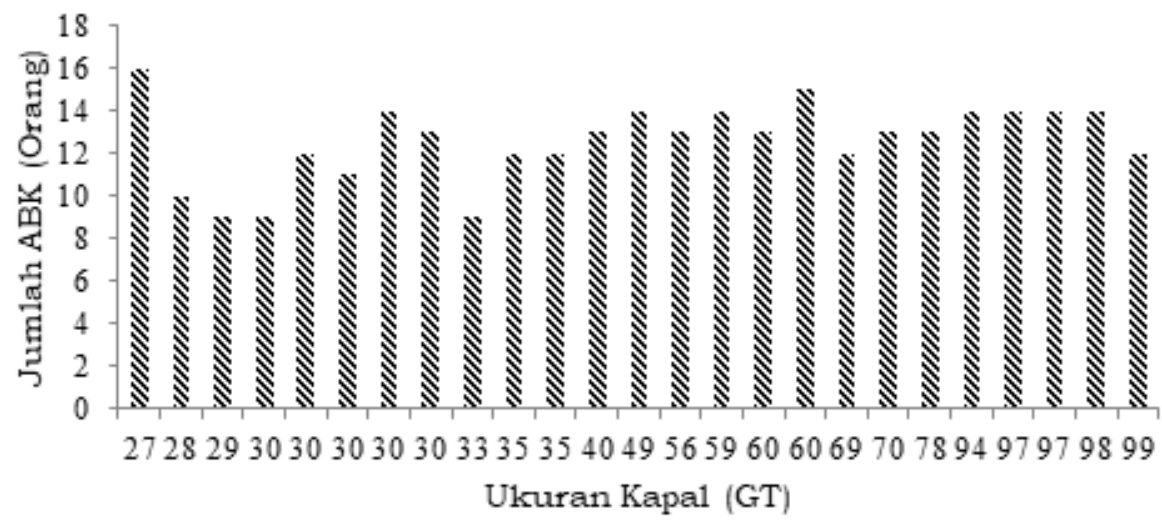

Gambar 6. Grafik jumlah ABK unit penangkapan bouke ami per ukuran kapal di PPN Muara Angke Jakarta Tahun 2020 


\section{Jumlah aktual kebutuhan perbekalan pada unit penangkapan bouke ami}

Berdasarkan wawancara dan observasi di lapang, perbekalan di PPN Muara Angke jumlah kebutuhan perbekalan masing-masing unit penangkapan bouke ami berbeda-beda. Dari masing-masing perbekalan melaut unit penangkapan bouke ami dari jumlah masing-masing perbekalan di setiap kapal bouke ami berbeda-beda. Perbekalan masing-masing unit penangkapan bouke ami jumlahnya berbeda-beda tergantung dari jumlah ABK, lama melaut dan tergantung pemilik kapal. Jumlah masing-masing perbekalan dari unit penangkapan bouke ami sudah diperhitungkan oleh nahkoda dan pemilik kapal kalaupun berkurang itu disebabkan oleh lama melautnya ditambah karena belum mendapatkan hasil tangkapan yang belum cukup. Perbekalan solar jika kurang maka nakhoda menghubungi pemilik kapal untuk meminta tambahan solar lalu pemilik kapal akan menitipkannya ke unit penangkapan bouke ami yang mau berangkat melaut ke fishing ground.

Dilihat dari Gambar 7 rata-rata jumlah perbekalan berdasarkan jumlah ABK yaitu 9-10 orang membutuhkan solar sebanyak 17.241 liter dengan harga $\mathrm{Rp}$ 162.065.400, oli sebanyak 201 liter dengan harga Rp 13.065.000, air bersih sebanyak 14.000 liter dengan harga $\mathrm{Rp}$ 532.000, beras sebanyak 2.988 liter dengan harga Rp 20.916.000, sayuran $50 \mathrm{~kg}$ seharga Rp 4.750.000, kopi sebanyak 1.000 bungkus seharga Rp 1.500.000, rokok sebanyak 1.000 bungkus seharga Rp 14.000.000, mie instan sebanyak 1.250 bungkus dengan harga Rp 3.750 .000 , dan gula sebanyak $50 \mathrm{~kg}$ dengan harga Rp 800.000. Adapun jumlah rata-rata jumlah ABK 11-12 orang membutuhkan solar 23.180 liter dengan harga $\mathrm{Rp}$ 217.892.000, oli 262 liter dengan harga $\mathrm{Rp}$ 17.030.000, air bersih 9.000 liter dengan harga Rp 342.000, beras 1.293 liter dengan harga Rp 9.051.000, sayuran sebanyak $60 \mathrm{~kg}$ dengan harga Rp 5.700.000, kopi sebanyak 1.083 bungkus dengan harga Rp 1.624.500, rokok sebanyak 966 bungkus dengan harga Rp 13.524.000, mie instan sebanyak 1.293 bungkus dengan harga $\mathrm{Rp}$ 3.879.000, dan gula sebanyak $83 \mathrm{~kg}$ seharga Rp 1.328.000. Selain itu rata-rata jumlah ABK 13-14 orang membutuhkan solar 23.972 liter dengan harga Rp 225.336.800, oli sebanyak 209 liter dengan harga Rp 13.585.000, air bersih sebanyak 12.307 liter dengan harga Rp 468.000, beras sebanyak 3.882 liter dengan harga Rp 27.174.000, sayuran sebanyak 73 kg dengan harga $\mathrm{Rp}$ 6.935.000, kopi sebanyak 1.307 bungkus dengan harga Rp 1.961.000, rokok sebanyak 1.123 bungkus dengan harga $\mathrm{Rp}$ 15.722.000, mie instan sebanyak 1.483 dengan harga Rp 4.449.000, dan gula sebanyak $100 \mathrm{~kg}$ dengan harga $\mathrm{Rp} \mathrm{1.600.000.} \mathrm{Sementara} \mathrm{rata-rata} \mathrm{jumlah}$ ABK 15-16 orang membutuhkan perbekalan solar sebanyak 22.988 liter dengan harga $\mathrm{Rp}$ 216.087.000, oli sebanyak 114 liter dengan

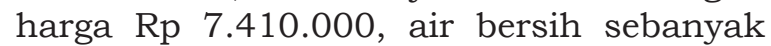
12.500 liter dengan harga Rp 475.000, beras sebanyak 5.312 liter dengan harga Rp 37.184.000, sayuran sebanyak $70 \mathrm{~kg}$ dengan harga Rp 6.650.000, kopi sebanyak 1.500 bungkus seharga Rp 2.250.000, rokok sebanyak 1.200 bungkus dengan harga Rp 16.800.000, mie instan sebanyak 1.400 bungkus dengan harga $\mathrm{Rp}$ 4.200.000, dan gula sebanyak $100 \mathrm{~kg}$ dengan harga Rp 1.600.000.

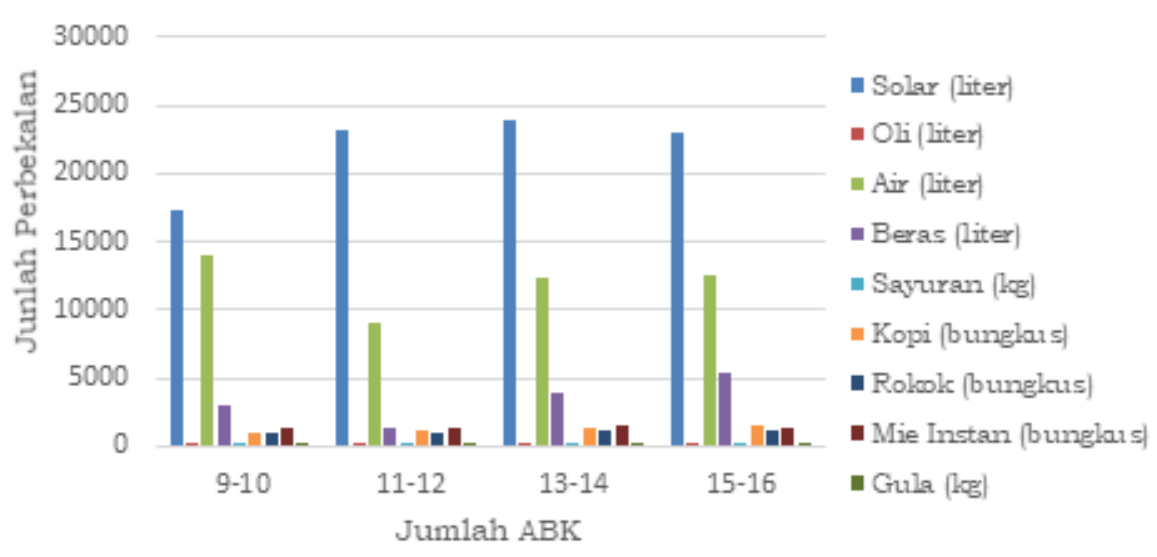

Gambar 7. Rata-rata jumlah perbekalan berdasarkan jumlah ABK 
Dilihat dari Gambar 8 jumlah modal perbekalan rata-rata $\mathrm{ABK}$ 9-10 orang berjumlah Rp 221.378.400, ABK 11-12 orang berjumlah $\mathrm{Rp} 270.370 .500$, ABK 1314 orang berjumlah Rp 297.230.800, ABK 15-16 orang berjumlah Rp 292.656.000. Dilihat dari Gambar 7 dan 8 dari jumlah masing-masing ABK 9-10, 11-12, 1314, 15-16 perbekalan solar, oli, tidak mempengaruhi banyaknya jumlah $\mathrm{ABK}$ karena solar dan oli ini dipengaruhi oleh lama trip dan jauh melaut. Jenis perbekalan air, bahan makanan seperti beras, sayuran, mie instan, kopi, rokok, dan gula cukup berpengaruh tetapi tidak signifikan karena selain jumlah ABK jenis perbekalan air, beras, sayuran, kopi, rokok, mie instan, dan gula yang mempengaruhi adalah lama trip. Berdasarkan data yang diperoleh dari hasil observasi dan wawancara, jumlah rata-rata perbekalan pada unit penangkapan bouke ami yang jumlah ABK nya 13-14 orang lebih banyak. Hal ini dikarenakan unit penangkapan bouke ami dengan ABK 1314 jumlahnya lebih banyak ditemukan di lapangan dari keseluruhan populasi.

Dilihat dari Gambar9rata-ratajumlah kebutuhan jenis perbekalan berdasarkan ukuran kapal yaitu <30 GT kebutuhan solar berjumlah 20.115 liter dengan harga $\mathrm{Rp}$ 189.081.000, oli berjumlah 172 liter jumlah harga $\mathrm{Rp} 11.180 .000$, air bersih berjumlah 12.000 liter dengan harga $\mathrm{Rp}$ 456.000, beras berjumlah 2.656 liter dengan jumlah harga Rp 18.592.000, sayuran berjumlah $60 \mathrm{~kg}$ dengan jumlah harga Rp 5.700.000, rokok berjumlah 950 bungkus dengan jumlah harga $\mathrm{Rp}$ 13.300.000, mie instan sebanyak 1.365 dengan jumlah harga $\mathrm{Rp}$ 4.095.000, kopi sebanyak 1.125 bungkus dengan jumlah harga Rp 1.687.500, dan gula sebanyak $69 \mathrm{~kg}$ dengan jumlah harga Rp 1.104.000. Adapun ukuran kapal 3150 GT kebutuhan solar berjumlah 22.068 dengan jumlah harga Rp 207.439.200, oli berjumlah 158 liter dengan jumlah harga Rp 10.270.000, air bersih berjumlah 7.800 liter dengan jumlah harga Rp 296.400, beras berjumlah 5.312 liter dengan jumlah harga Rp 37.184.000, sayuran berjumlah $70 \mathrm{~kg}$ dengan jumlah harga $\mathrm{Rp}$ 6.650.000, rokok sebanyak 1.120 bungkus dengan jumlah harga Rp 15.680.000, mie instan sebanyak 1.448 bungkus dengan jumlah harga Rp 4.344.000, kopi sebanyak 1.100 bungkus dengan jumlah harga Rp 1.650.000, dan gula sebanyak $90 \mathrm{~kg}$ dengan jumlah harga Rp 1.440.000. Ukuran kapal 51-100 GT rata-rata kebutuhan solar sebanyak 24.425 liter dengan jumlah harga Rp 229.595.000, oli berjumlah 219 liter dengan jumlah harga Rp 14.235.000, air bersih berjumlah 12.917 liter dengan jumlah harga Rp 490.846, beras berjumlah 3.873 liter dengan jumlah harga Rp 27.111.000, sayuran berjumlah $69 \mathrm{~kg}$ dengan jumlah harga $\mathrm{Rp}$ 6.555.000, rokok berjumlah 1.116 bungkus dengan jumlah harga Rp 15.624.000, mie instan berjumlah 1.390 bungkus dengan jumlah harga Rp 4.170.000, kopi berjumlah 1.166 bungkus dengan jumlah harga Rp 1.749.000, dan gula berjumlah $96 \mathrm{~kg}$ dengan jumlah harga Rp 1.536.000.

Berdasarkan Gambar 10 jumlah modal rata-rata semua jenis perbekalan berdasarkan ukuran kapal adalah kapal berukuran <30 GT berjumlah Rp 245.195.500, sedangkan kapal yang berukuran 31-50 GT berjumlah Rp 284.953.600, dan yang terakhir kapal berukuran 51-100 GT berjumlah Rp 301.065.846.

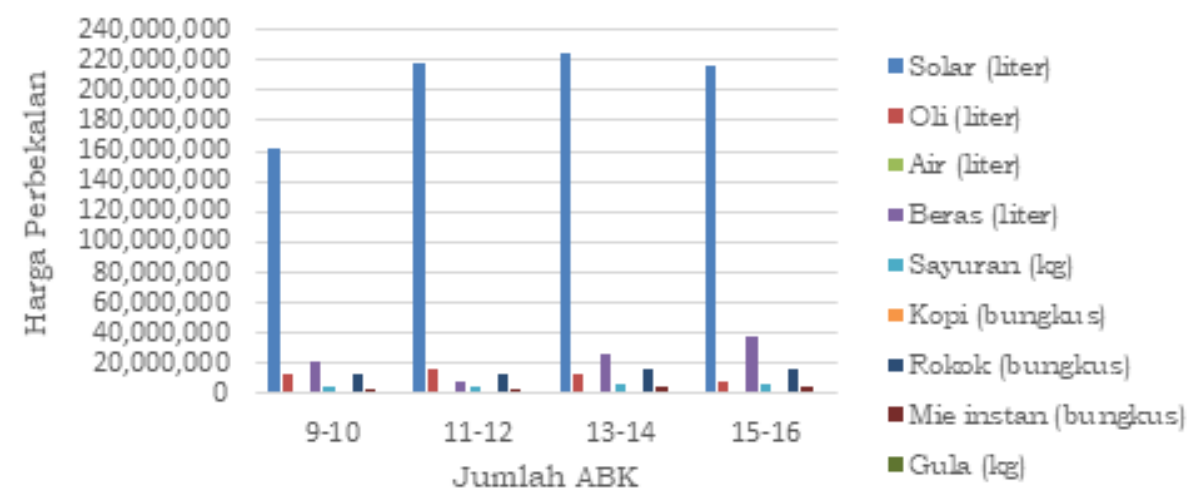

Gambar 8. Rata-rata harga perbekalan berdasarkan jumlah ABK 


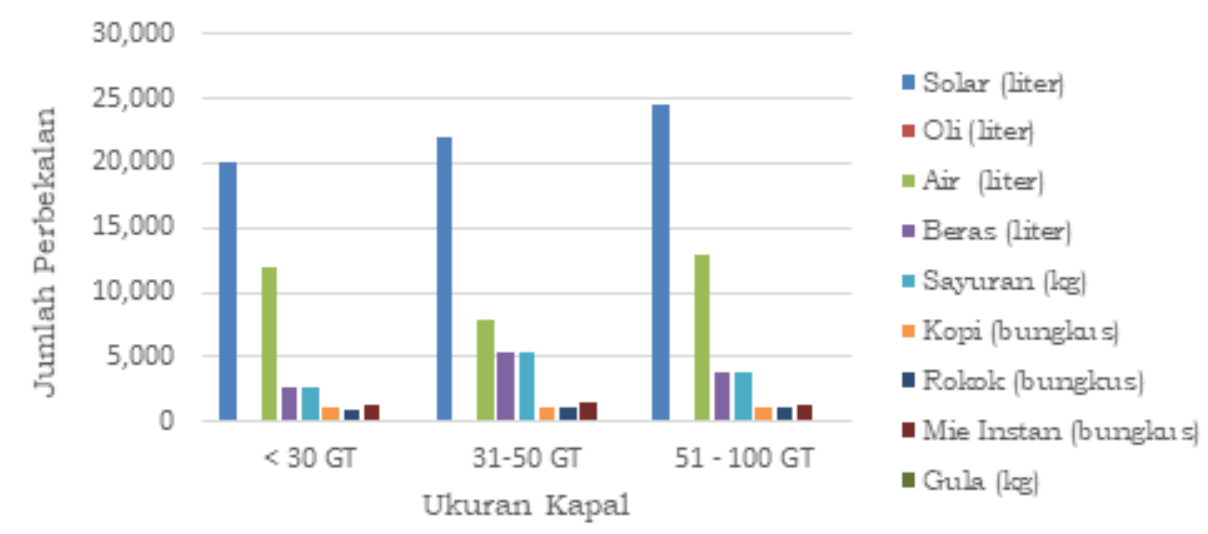

Gambar 9. Rata-rata jumlah perbekalan berdasarkan ukuran kapal

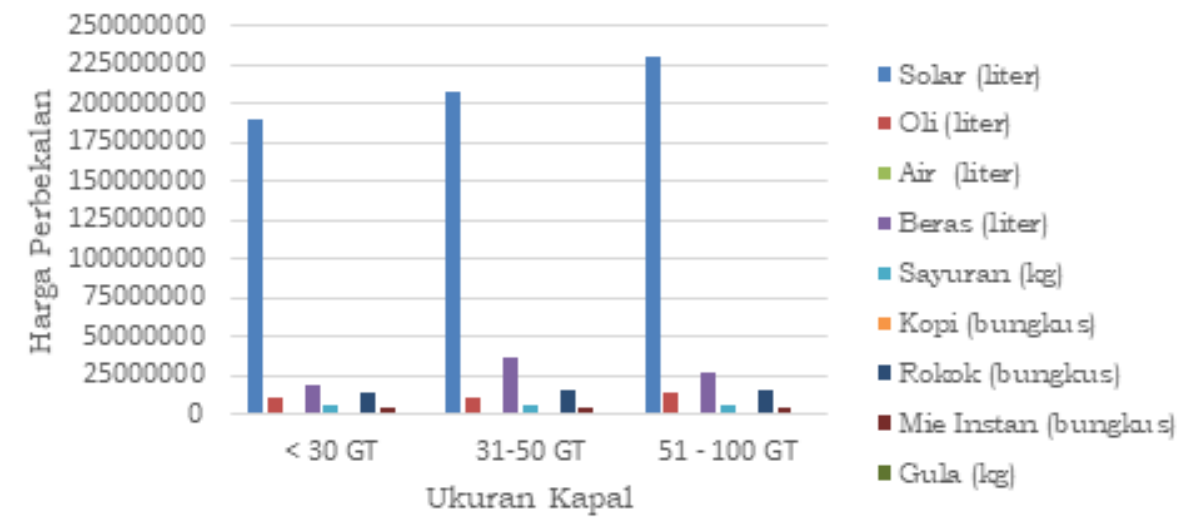

Gambar 10. Rata-rata jumlah harga perbekalan berdasarkan ukuran kapal

\section{Penanganan perbekalan unit penangkapan bouke ami}

Aktivitas pengisian perbekalan biasanya dilakukan tergantung kondisi cuaca pada saat itu. Pengisian berlangsung dari pagi hingga sore hari dan dapat dilakukan bertahap hingga dua hari apabila dalam kondisi cuaca buruk. Agen perbekalan yang bertugas akan melakukan pemesanan pada distributor. Oli yang didapatkan berasal dari luar kawasan pelabuhan, air bersih serta bahan makanan seperti beras, sayuran, didapatkan melalui pihak ketiga dan keseluruhannya didistribusikan melalui truk angkut sedangkan pengisian solar dilakukan di stasiun pengisian bahan bakar yang berada di dalam kawasan PPN Muara Angke Jakarta. Jenis perbekalan lain seperti kopi, rokok, dan mie instan juga dibeli melalui pihak ketiga dan di-packing ke dalam beberapa dus. Selanjutnya, setelah pengadaan barang yang dipesan telah selesai dilakukan, transaksi pembayaran dilakukan secara tunai. Apabila semua perbekalan sudah dimuat ke dalam kapal, ABK bagian perbekalan akan melakukan pengecekan kelengkapan perbekalan dan petugas pelabuhan melakukan pemeriksaan terhadap perbekalan tersebut. Terakhir, ABK yang bertugas mengisi form perbekalan dan barulah petugas pelabuhan memberi izin keberangkatan kapal tersebut untuk melaut.

Berdasarkan Gambar 11, tahapan penanganan perbekalan berawal dari agen bagian perbekalan yang memesan semua jenis perbekalan lalu semua jenis perbekalan membawa perbekalan tersebut dengan truk, setelah transportasi membawa perbekalan sampai di Pelabuhan Perikanan Muara Angke semua ABK di suatu unit penangkapan bouke ami bergotong royong mengisi semua jenis perbekalan. Jenis perbekalan seperti solar, air bersih terletak di buritan perbekalan oli terletak di ruang mesin, sayur-sayuran, dan bumbu masak diletakkan di palka dan jenis perbekalan beras, mie instan, kopi, dan rokok diletakkan di ruang nakhoda, setelah meletakkan semua jenis perbekalan ABK memeriksa semua jenis perbekalan apakah sudah lengkap, lalu petugas pelabuhan memeriksa perbekalan dengan membawa 
form perbekalan apabila sudah lengkap form perbekalan maka kapal bouke ami siap untuk beroperasi.

Menurut Martopo (2001) penanganan muatan merupakan suatu istilah dalam kecakapan pelaut, yaitu pengetahuan tentang memuat dan membongkar muatan dari dan ke atas kapal sedemikian rupa agar terwujud lima prinsip pemuatan yang baik. Lima prinsip pemuatan yang baik diantaranya melindungi awak kapal dan buruh, melindungi kapal, melindungi muatan, melakukan muat bongkar secara tepat dan sistem atas serta penggunaan ruang muat semaksimal mungkin.

Tata letak jenis perbekalan unit penangkapan bouke ami dapat dilihat pada Gambar 12. Solar terletak di buritan yang sudah disimpan di dalam drum karena tempatnya kering dan tidak terkena sinar matahari sehingga solar aman diletakkan di tempat tersebut. Oli terletak di ruangan dekat mesin yang kering dan tidak terkena sinar matahari agar mudah dijangkau di saat mengganti oli mesin kapal yang disimpan di dalam drum. Air bersih terletak di buritan disimpan dalam drum lalu diletakkan di tempat yang kering. Beras disimpan dalam karung diletakkan di kamar nakhoda. Mie instan yang sudah dibungkus dalam dus diletakkan di kamar nakhoda. Sayur dan buah-buahan jenis perbekalan ini dengan mudah dapat dirusak oleh perbekalan yang mengandung bau muatan basah dan muatan kotor atau berdebu, perbekalan ini harus disimpan di tempat yang sejuk untuk mempertahankan kesegaran perbekalan agar tidak busuk menghambat kegiatan tumbuhnya mikroorganisme. Kopi instan jenis barang ini sudah dikemas dalam bentuk dus diletakkan di kamar nakhoda. Gula dimuat dalam karung lalu diletakkan di kamar nakhoda. Rokok dimuat dalam dus diletakkan di kamar nakhoda.

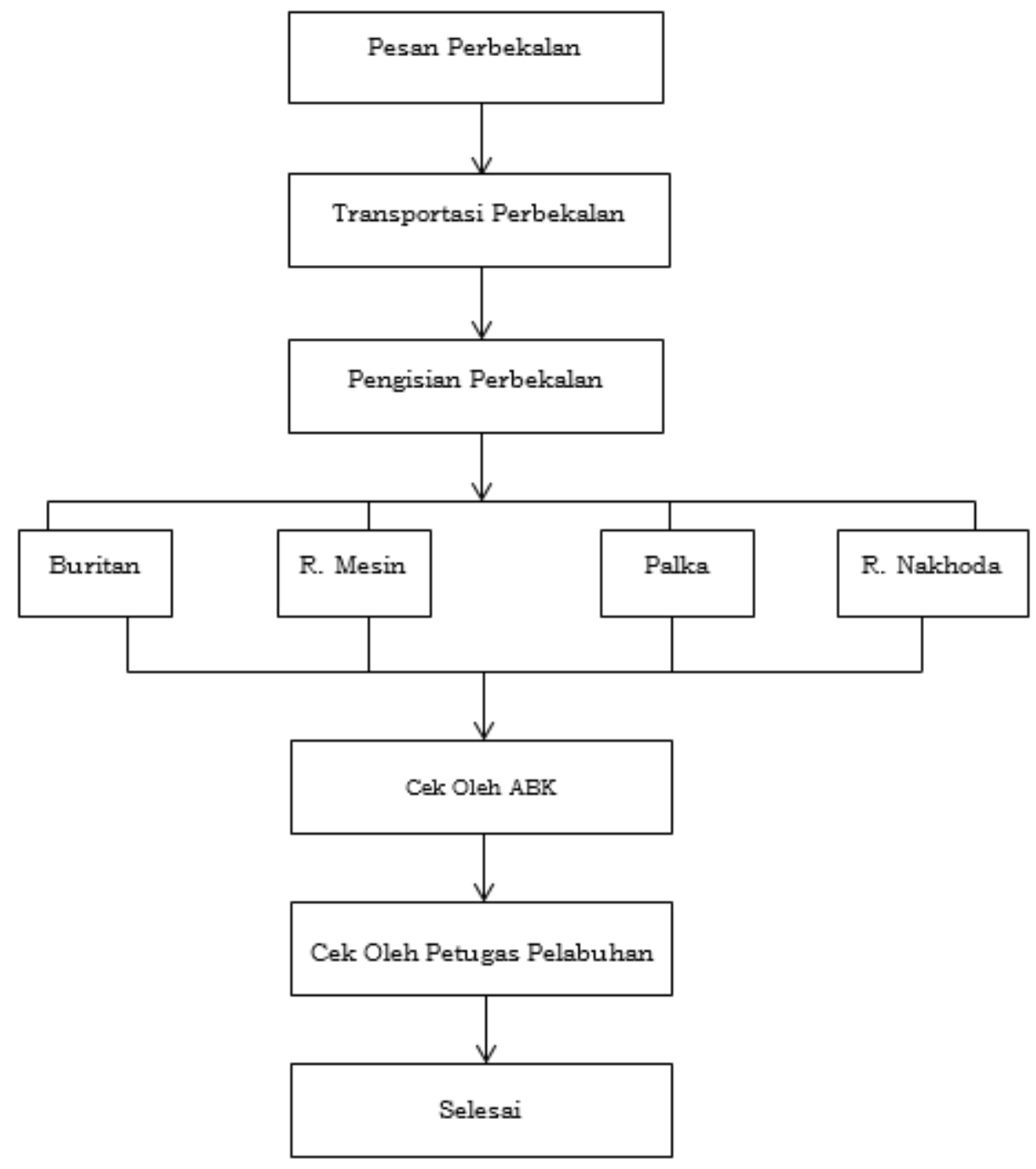

Gambar 11. Diagram alir penanganan perbekalan di kapal 

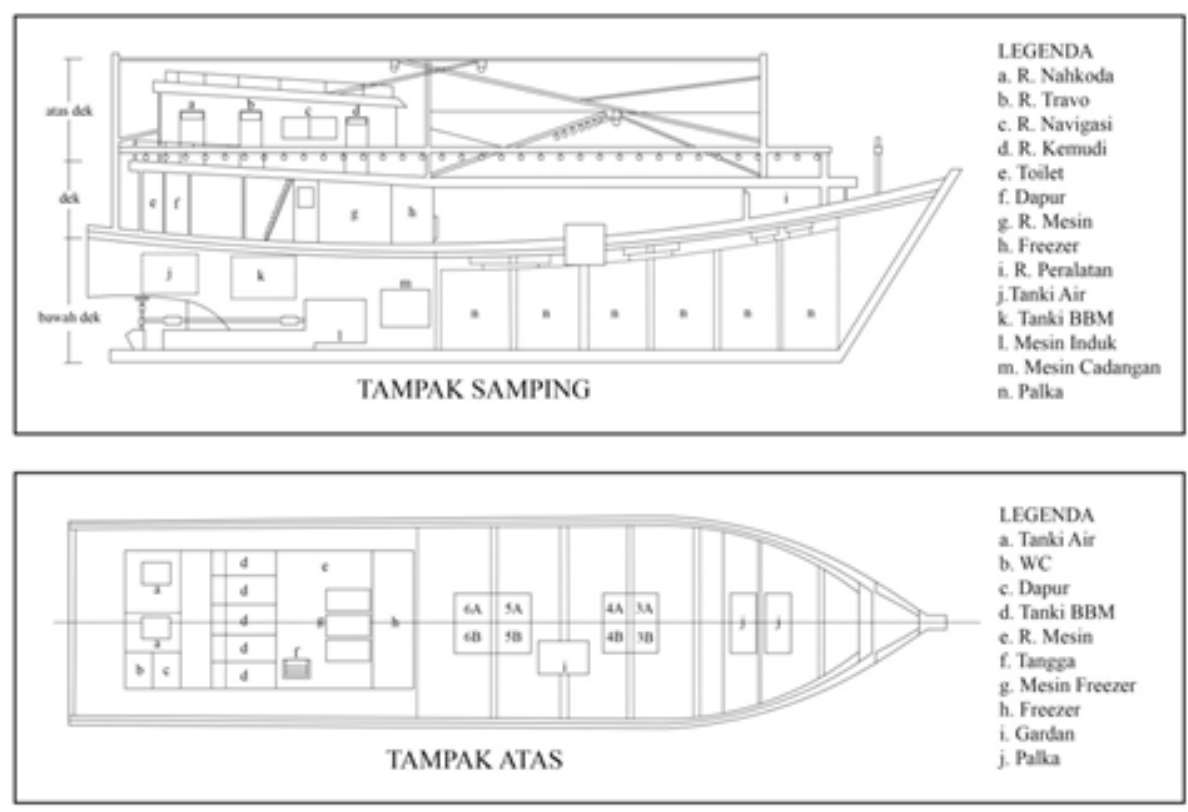

Gambar 12. Tata letak perbekalan di atas kapal

\section{KESIMPULAN DAN SARAN}

\section{Kesimpulan}

Kapal bouke ami di PPN Muara Angke yaitu berukuran 10-200 GT didominasi oleh kapal yang berukuran 21-30 GT. Bagian alat tangkap bouke ami bagian jaring terdiri dari kantong, badan jaring, dan kaki jaring. Bagian tali terdiri dari tali kolor dan tali kerek, bagian lainnya pemberat, cincin, dan rig. Kapal bouke ami terdapat mesin berpendingin, winch hauler, radio contact, dan VMS (Vessel Menitoring System). Metode penangkapan terdiri dari persiapan, setting, dan hauling. Nelayan yang terdiri dari 9-16 orang mempunyai peran masing-masing.

Jenis perbekalan yang dibutuhkan adalah solar, oli, air bersih, minyak goreng, sayuran, mie instan, kopi, rokok, gula, dan obat-obatan. Perbekalan tersebut dipersiapkan oleh agen perbekalan unit penangkapan. Jumlah kebutuhan perbekalan masing-masing kapal berbeda tergantung jumlah ABK, jarak DPI, ukuran GT kapal, dan lama melaut.

Sistem penanganan perbekalan unit penangkapan bouke ami di PPN Muara Angke sudah cukup baik, dipesan oleh agen sudah di-packing dengan baik, bahan sayuran yang disimpan di bagian palka, solar dan oli di bagian belakang kapal, dan obatobatan, gula, teh, dan kopi di bagian kamar nakhoda. Apabila perbekalan tersebut berlebih maka tetap digunakan untuk trip berikutnya, dan apabila perbekalan melaut kurang maka nakhoda akan menghubungi pemilik kapal yang berada di darat lalu pemilik kapal akan menitipkan perbekalan tersebut ke kapal yang akan mau berangkat melaut.

\section{Saran}

Perlu adanya pencatatan data yang detail spesifikasi perbekalan, antara lain mencatat jenis, kualitas, merk, dan jumlah dan pihak PPN Muara Angke perlu memiliki data lengkap mengenai perbekalan melaut agar antara pihak nelayan dan pelabuhan terkoordinir. Pemilik kapal dan agen perbekalan perlu mempunyai dan mengetahui lebih rinci menganalisa kebutuhan dari berbagai jenis perbekalan.

\section{DAFTAR PUSTAKA}

Alvionita D. 2018. Sistem Bagi Hasil Usaha Penangkapan Cumi-Cumi (Loligo $s p$ ) Menggunakan Alat Tangkap Bouke Ami (Stick Held Dip Net) yang Didaratkan di Pelabuhan Perikanan Samudera Belawan Provinsi Sumatera Utara [Skripsi]. Riau (ID): Universitas Riau.

Dinita A, Rosyid A, Ismail. 2015. Analisis Kebutuhan Perbekalan dan Fasilitas Fungsional di Pelabuhan Perikanan Pantai (PPP) Tegalsari, Kota Tegal. 
Journal of Fisheries Resources Utilization Management And Technology. 4(4): 170-178.

Fitriyashari A, Rosyid A, Ayunita D. 2014. Analisis Kebutuhan Perbekalan Kapal Penangkap Ikan di Pelabuhan Perikanan Pantai di Tasikagung, Rembang. Jurnal of Fisheries Resources Utilization Management and Technology. 3(3): 122-130.

[KKP] Kementerian Kelautan dan Perikanan Republik Indonesia. 2010. Keputusan Menteri Kelautan dan Perikanan Republik Indonesia Nomor 6 Tahun 2010 tentang Alat Penangkapan Ikan di Wilayah Pengelolaan Perikanan Negara Republik Indonesia.

Kotdriyah N. 2019. Strategi Operasi Penangkapan dan Adaptasi Nelayan Bouke ami di Pelabuhan Perikanan Nusantara Muara Angke [Skripsi]. Bogor (ID): Institut Pertanian Bogor.

Martopo A. 2001. Penanganan Muatan. Semarang (ID): Politeknik Ilmu Pelayaran Semarang.

Monintja D, Martasuganda S. 1989. Teknologi Penangkapan Ikan [Diklat Kuliah]. Bogor(ID): Institut Pertanian Bogor.

Nugroho. 2019. Antisipasi Kecelakaan Laut, Basarnas Imbau Kapal Ikan Pasang Alat Deteksi Dini. https:// news.detik.com/berita/d-4755268/ antisipasi-kecelakaan-lautbasarnas-imbau-kapal-ikan-pasangalat-deteksi-dini/2. [26 November 2019].
Rifan BM, Boesono H, Hapsari TD. 2016. Analisis Finansial Alat Tangkap Jaring Cumi di Pangkalan Pendaratan Ikan Muara Angke Jakarta Utara. Prosiding Seminar Nasional Tahunan ke-V Hasil Penelitian Perikanan dan Kelautan; 2016 Juni 366-380; Semarang, Indonesia. Semarang (ID): Universitas Diponegoro.

Rooskandar BP. 2014. Analisis Produksi Cumi-Cumi Unit Penangkapan Bouke Ami di PPS Nizam Zachman Jakarta [Skripsi]. Bogor (ID): Institut Pertanian Bogor.

Saleh S. 2016. Administrasi Perbekalan/ Logistik. Bandung (ID): Pustaka Ramadhan.

Sudirman, Mallawa A. 2012. Teknik Penangkapan Ikan Edisi Revisi. Jakarta (ID): Rineka Cipta.

Sugiyono. 2010. Metode Penelitian Pendidikan Pendekatan Kuantitatif, Kualitatif, dan R\&D. Bandung(ID): Alfabeta.

Undang-Undang Republik Indonesia Nomor 9 Tahun 1985 tentang Perikanan.

UPT Muara Angke. 2020. Laporan Tahunan 2020. [UPT] Unit Pelaksana Teknis Kawasan Pelabuhan Perikanan dan Pangkalan Pendaratan Ikan. Jakarta.

Yahya MF, Ilhamdi H. 2018. Aspek Operasional Penangkapan Kapal Bouke Ami yang Berbasis di TPI Muara Angke. Jurnal Buletin Teknik Litkayasa. 16(1): 1-5. 